DOI 10.37882/2500-3682.2021.10.02

\title{
СИМВОЛИЗМ ВЕЛИКИХ ПОБЕД В РОССИЙСКОМ СОЗНАНИИ
}

\section{SYMBOLISM OF THE GREAT VICTORIES IN RUSSIAN CONSCIOUSNESS}

\section{Zh. Andrievskaya}

Summary: This article is devoted to the consideration of the role of great military victories as a factor in the process of the formation of Russian consciousness and self-awareness. The article analyzes the impact of the millennial tempering, forged in great victories, on the formation of the Russian character and the Russian will to victory. The article considers the "firmware» of the memory of great victories in the cultural code of our nation, their significance in the self-consciousness of the Russian nation - as a nation of victors. Having received a consolidation in the historical memory of the peoples of the world, the idea of Russia's invincibility underlies its external relations and demeanor on the world stage.

Keywords: russian consciousness, great victories, symbolic programs, Russian cultural code.

\author{
Андриевская Жанна Викторовна \\ K.nсх.н., доцент, Южный Федеральный Университет \\ zhandan3@gmail.com
}

Аннотация: Данная статья посвящается рассмотрению роли великих военных побед как фактора в становлении российского сознания и самосознания. Подвергается анализу воздействие закалки, выкованной в великих победах, на формирование российского характера и российской воли к победе. Рассматривается «прошивка» памяти о великих победах в культурный код нашей нации, их значение в самосознании российской нации как нации победителей. Получив закрепление в исторической памяти народов мира, представление о несокрушимости России фундирует её внешние отношения и манеру поведения на мировой арене.

Ключевые слова: российское сознание, великие победы, символические программы, российский культурный код.
$P$ оссийская история есть история великих побед в крайне масштабных войнах. Нося, прежде всего, оборонительный, а отнюдь не завоевательный, характер, великие победы есть своего рода «визитная карточка» нашей страны, ведь, как известно, «кто к нам с мечом придёт, тот от меча и погибнет». Эти перманентные военные столкновения нередко распадались на войны на нескольких фронтах (нередко более двух и свыше), с несколькими странами сразу (например, Третьим Рейхом и Японией в Великой Отечественной Войне) и характеризовались крайней степенью кровопролитности, забирая с собой жизни миллионов. Такая специфика исторического пути российского народа не могла не наложить свой отпечаток на способ мышления россиян, возбуждая в нём - как и в российской рациональности, российской ментальности, российской психологии - оборонительные настроения (что предельно рельефным образом отразилось в политике СССР, где на оборонные нужды бросались едва ли не все возможные и невозможные силы).

Так, «9 мая 1945 г. была поставлена победная точка в Великой Отечественной войне советского народа против фашистской Германии и ее союзников. В 2015 г. Россия широко и торжественно отметила 70-летие этого эпохального события. Праздничные мероприятия прошли в городах и весях всей страны. В них приняли непосредственное живое участие миллионы и миллионы людей, тем самым продемонстрировав миру, что российский народ помнит, понимает и ценит великий подвиг поколений военных лет, сокрушивших германский фашизм» [Бельков, С. 5]. Сокрушив в очередной раз агрессивного захватчика, советский народ проявил волю к победе и стремление к национальной свободе.

Наша страна прошла через многие военные испытания, и в этой связи отнюдь неслучайна героизация этих великих побед - над Ордынским ли Игом, над войсками Наполеона ли, над Третьим ли Рейхом. Проявляя всякий раз выраженное народное единство, наши предки собирали всю свою волю к победе «в кулак», и отражали целостным образом различные нападения извне: откуда бы ни исходила агрессия по отношению к нашей стране - от Запада ли, от Востока ли - наши деды и прадеды выступали сплочённым фронтом в каждый из таких моментов.

В этом смысле Великая Отечественная Война является символом победы, что формирует вокруг себя целое семейство символических программ мышления российского человека: начиная с символизма Георгиевской ленточки, и заканчивая масштабными парадами на Красной Площади, в которых принимают участие тысячи человек. Нетрудно понять, что современные Парады Победы носят, прежде всего, символический характер, они выковывают символические смыслы и значения, впитывающиеся умами россиян в качестве живой презентации того самого исторического опыта нашего народа (как и всех иных российских народов), который потребовал от всех народов России предельной мобилизации внутренних сил и личностных ресурсов каждого в некий критический момент.

В этом смысле первая и важнейшая благодетель предводителей страны - Царя ли, Генерального ли Секретаря, 
Президента, какого-либо иного полководца - это благодетель Победы над захватчиками, преодоления внешней угрозы, которая может настигнуть Родину едва ли не с любой стороны её границ, попытается проникнуть едва ли не с любой точки границ страны - причём как по земле, так и по морю, как по воздуху, так под водой.

Так, «в то же время Победа показала всему миру безнадежность попыток разговаривать с Россией с позиции силы. Она закрепила в исторической памяти мира, наших друзей и геополитических соперников понимание бесперспективности силового противоборства с Россией» [Бельков, С. 7]. Символы наших Побед - так или иначе, во всех произошедших войнах - оказываются мощной заслонкой для разрушительных идей и мыслей покорения нашей Великой Родины, как и вообще всяких возникающих помыслов сломить Россию.

Подогреваемая попытками «изолировать» Россию, поставить её в зависимое состояние, ввести против неё те или иные «санкции», память о великих победах только лишь усиливается в сторону поднятия патриотических настроений в нашем обществе, только лишь возвеличивает понимание особой роли нашей страны в общемировом контексте, её особой исторической миссии и её цивилизационного предназначения, взращивая непоколебимость и стойкость в отношении любых и всяких внешних попыток сдержать влияние нашей страны в мировом контексте.

Символические программы, закладываемые этими праздниками в мышлении россиян - это, напр., ценность российского интернационализма как продолжение, следствие ценности борьбы с фашистами, нацистами (ядро Дня Победы, разумеется). Символизм Дня Победы - это, разумеется, и Георгиевская лента, и бессмертный полк с его фотографиями героев войны, и парад военной техники на Красной Площади (о чём в широком культурном горизонте см. выше).

А ведь именно память о Великих Победах - но, беря её уже в политической плоскости - оказывается основанием ведения внешней политики (напр., борьба с украинскими про-нацистскими политическими силами), солидарности в мировом масштабе (напр., между Россией и Израилем). Беря политический срез подобных символических действ, нельзя не обратить внимание на то, что они формируют ландшафт приоритетов внешнеполитических взаимодействий и дипломатии, - напр., отношений между Россией и Китаем, основания которых были заложены ещё в Советский период истории России (и Китай понёс весьма значительные потери в его борьбе с фашистской Японией).

Так, например, беря иной пример великой победы, а именно победы над Ордынским Игом, принято замечать, что «аналогия между «вавилонским пленением» иудеев и «ордынским пленением» Руси позволяла не только отыскать необходимый в таких случаях по законам средневековой историографии прообраз происходящего в Священной истории человечества, но и актуализировать «идеологию выживания» в условиях иноземного владычества» [Рудаков, С. 29] - эта «идеология выживания», в дальнейшем проявленная, напр., в Блокаде Ленинграда, уже навсегда зафиксировалась в памяти российского народа; в этой связи обычно принято говорить, что «русские не сдаются» - и подчёркивать, акцентировать характер российской воли к победе; пройдя тысячелетнюю закалку, выкованная в великих победах, российская воля к победе уже никогда не сможет быть сломлена никакой возможной агрессией - и всякие планы поставить нашу страну в зависимое положение уже навсегда терпят крах. В этой связи нетривиально, что ни одна страна мира не имеет опыта ведения военных действий, аналогичного нашему, и этот опыт уже навсегда закрепился в нашем «культурном коде».

В этой связи особое российское национальное мышление погружено в объемлющий контекст самосознания, обнаруживая себя, прежде всего, в истории - это победы в таких жутких, кровопролитных войнах, как свержение Ордынского ига, победа над Наполеоном, победа над Третьим Рейхом.

Российское национальное самосознание формируется именно через призму великих военных Побед, и - в силу географических причин - едва ли может быть иным. Именно великие Победы определяют облик российского национального самосознания - неслучайно в этом контексте именно 9 мая является той великой общенациональный духовной «скрепой», которая объединяет всю российскую нацию. Кучуков М. пишет: «государство, в котором мы живем, уникально и своей историей, и огромной территорией, и трагическими для жизни народов страницами глобальных социальных экспериментов. Российское государство исторически возникло на пересечении разных парадигм цивилизационного развития, объединило народы, отличающиеся друг от друга по уровню социального развития и культуре, расовому облику и численности» [Кучуков, С. 124]; как следствие, самосознание российской нации, и русского народа как конституирующего её, формируется через противопоставление различного рода захватчикам, которые издавна приходили «с мечом» на нашу страну, и получали соответствующий «отпор». Именно великие военные победы оказываются духовными общенациональными «скрепами», которые объединяют народы и этносы в единую российскую нацию, именно в них содержится тот самый исторически бессмертный консолидирующий потенциал.

Но более того: всякая великая победа носит освобо- 
дительный характер; напр., «победа русской армии в Отечественной войне 1812 года создала предпосылки для освобождения всей Европы от наполеоновского господства» [Шевченко, С. 263], не говоря уже об освобождении Европы от коричневой чумы. В этой связи открывается мировая миссия России - а именно миссия страны-освободительницы ото всяких сторонних узурпаторов, пытающихся построить свои «империи» на костях своих и чужих людей: а ведь как Орда и Французская империя, так и Третий Рейх полагали своими предельными целями «мировое господство», пытались реализовать свои имперские амбиции.

Беря более широкий контекст, в символической составляющей великих побед, стоит указать, что, например, День Победы как символическая программа включает социальные поступки (например, поздравления ветеранов), социальные действия (символические ношение Георгиевских лент на одежде), социальную практику - самоидентификацию населения страны с образом народапобедителя, и, соответственно социальную событийность - торжественные мероприятия (скажем, мероприятия на Красной Площади в день 9 мая). Тем самым перманентная внешняя агрессия является одним из внешних факторов, формирующим символические программы российского мышления, особенно в вопросах Великих Побед - над Ордынским ли Игом, Французской ли Империей, Третьим Рейхом, эта специфика накладывает неизгладимый отпечаток на символические программы и формирует особую ментальность нации победителей. Эти великие Победы, достигнутые ценой миллионов жизней, оказываются бессмертным историческим фоном ведения современной политики - как внешней, так и внутренней; они символически фиксируются в таких мощнейших образах, как Георгиевская ленточка, и закрепляются в бессознательных пластах коллективной памяти, формируя и определяя ландшафт архетипических структур общественного бессознательного.

Эта нация победителей, в культурном коде которой заложены мощнейшие и неистребимые установки на победу, всегда играла и играет свою роль на мировой арене - во всяком случае, с момента строительства единого централизованного русского государства, и - далее - Российской империи, Советского союза, Новой России. В культурном коде нации победителей заложены такие установки, как «русские не сдаются», «русские своих не бросают» - эти установки буквально «прошиты» в нашем коде, и они решающим образом влияют на наше поведение и нашу деятельность, особенно - в т.н. «пограничных» ситуациях, в военное время, требующего проявления от человека особого героизма, лучших патриотических качеств, а нередко - вовсе самопожертвования ради Родины и её будущего; великие победы - средоточие символических программ российского мышления; они заложены в нашем национальном сознании и самосознании, и не могут быть искоренены из него никакой сторонней пропагандой уже никогда.

\section{ЛИТЕРАТУРА}

1. Бельков, 0.А. Великая победа и современность // Власть, 2015'05, С. 5-8.

2. Купцов, В.П. Победа Советского народа в Великой Отечественной войне: проблемы историографии // Вестник Российского экономического университета им. Г.В. Плеханова, 2010, №2. С. 129-138.

3. Кучуков, М.М. Национальное самосознание: интерпретация социального содержания и роли. Тамбов: Грамота, 2015. № 10 (60): в 3-х ч. Ч. І.

4. Нолев, Е.В. «Монголо-татарское иго»: идеологический и методологический аспекты исторического дискурса // Вестник Бурятского государственного университета. Философия. 8/2013, С. 92-96.

5. Рудаков, В.Н. Концепция ордынского «ига» и отношения с Ордой в русском общественном сознании второй половины XIII - XVI веков. Вестник MГИм0Университета. 2012;(4(25)):24-32.

6. Шевченко, В.Н. Отечественная война 1812 г. // Вестник университета. 08/2013. С. 260-263.

(c) Андриевская Жанна Викторовна (zhandan3@gmail.com). 